\title{
Michigan's Continuing Abolition of the Death PenAlty AND THE CONCEPTUAL COMPONENTS of Symbolic Legislation
}

\author{
LARRY W. KOCH \\ University of Michigan-Flint
}

AND

JOHN. F. GALLIHER

University of Missouri-Columbia

\section{INTRODUCTION}

HE UNITED States is unique in that it is the only western industrialized democracy retaining a death penalty. However, due to US Supreme Court action in 1972 (Furman v Georgia), the overwhelming majority of death penalty statutes were found to be constitutionally questionable. Indeed, no further executions occurred until the states found a constitutionally acceptable formula for capital punishment in 1976 (US Department of Justice, 1992). As of 1990, thirty-six states had constitutionally valid death penalty statutes, but twenty of these states had failed to resume executions (US Department of Justice, 1992). This suggests a de facto abolition of the death penalty in some states. Aside from the four-year hiatus imposed by the Supreme Court, twenty-one American

Social \& Legal Studies (SAGE, London, Newbury Park and New Delhi), Vol. 2 (1993), 323-346 
states have at some time abolished the death penalty (US Department of Justice, 1981; McGarrell and Flanagan, 1985). Of these, eight have done so for less than ten years. Seven others have repealed the punishment for between twenty and forty-five years. Only six states have repealed the death penalty for over seventy years. Rhode Island repealed the death penalty in 1852, restored it in 1973 and the state supreme court abolished it again in 1979. Maine abolished the death penalty in 1876, restored it in 1883 and repealed it again in 1887. North Dakota repealed the death penalty in 1915, Minnesota in 1911, Wisconsin in 1853 and Michigan in 1847. With over 140 years of abolition, Michigan is atypical among American states, as well as being a curious candidate for such a distinction.

Hugo Adam Bedau, the dean of death penalty researchers, has noted that:

[a]s early as the 1830 s, legislatures in several states ... were besieged each year with petitions from their constituents on behalf of total abolition. Special legislative committees were formed to receive these messages, hold hearings, and submit recommendations. ... With the forces arrayed against slavery ... the anti-gallows societies were among the most prominent groups struggling for social reform in America. The high-water mark was reached in $1846 \ldots$ and Michigan . . became the first English-speaking jurisdiction in the world to abolish the death penalty. ... One naturally wonders what has been the experience in those few jurisdictions [such as] Michigan ... that have long relied on imprisonment rather than death as the penalty for even the gravest crimes. .. As for longtime abolitionist states such as Michigan .. . historians seem to have ignored their experience. ... In any case, most of the nation's population has never had the opportunity to be persuaded in favor of abolition either by experiencing it directly or by being told the full story of how crime and punishment, social vindictiveness, and fear of violence are managed without recourse to the threat of executions. (Bedau, 1982:21-4)

\section{Violence, Racial Immigration and the Death Penalty}

From 1945 to 1954 Michigan had a mean murder rate of 4.4 per 100,000 and ranked 26th among all US states. During the period from 1955 to 1964 the state had a murder rate of 3.8 and ranked 27th. From 1965 to 1974 the murder rate more than doubled, reaching 8.7 per 100,000, which ranked Michigan 16th among the states. During the period 1975 to 1984 Michigan had a mean murder rate of 10.0, ranking it 14th (US Department of Commerce, 1947-86). In 1983 Michigan ranked 9th in murder rates (Federal Bureau of Investigation, 1983:52-63). During the last twenty years Michigan has been second in murder rates among abolitionist states, behind only Alaska (US Department of Commerce, 1967-86). Approximately 50 percent of all executions between 1945 and 1964 were in the ten states with the highest mean murder rates (McGarrell and Flanagan, 1985; US Department of Commerce, 1947-66), while these states contained only 25 percent of the total national population (US Department of Commerce, 1982). Clearly, Michigan is an exception to the generally positive relationship between levels of violence and the presence and use of the death penalty. 
Michigan's racial and ethnic characteristics also contradict continued abolition. Immigration patterns in Michigan have involved blacks and whites, European and domestic. Blue-collar employment in a booming auto industry continued to increase until the late 1920s and large numbers of blacks and poor whites moved into the state from the south. Michigan ranked 4th in gains of blacks between 1900 and 1970, and ranked 16th in percent black in 1970 (US Department of Commerce, 1975), the only continuously abolitionist state in the top twenty. In Detroit the percentage of blacks declined from 3.1 percent in 1860 to 1.2 percent fifty years later. In 1910 the black community numbered approximately 5000 persons. But between 1919 and 1940 the percentage of blacks in the city increased from 1.2 to 9.2 percent. 'Whites had dominated the influx during the $1920 \mathrm{~s}$. . . but blacks accounted for over 52 percent of the ... increase in the following decade' (Capeci, 1984: 9). Nearly half of the migrants were southerners, this percentage increasing substantially after 1942. Lee and Humphrey (1943) noted that Detroit had only 10,000 black citizens in 1916, but approximately 220,000 by 1943 . In a mere three years, 1940-3, 440,000 whites moved into the city, primarily from the south. Lee and Humphrey (1943: 92) quoted a Michigan social worker who explained that these southern whites: 'are ignorant and hold traditional southern attitudes towards Negroes. Socially, they are classed with the "foreign" elements in Detroit. They are in great need for compensation - to look down on other groups. The Negroes make a convenient target.' 'By 1948, almost half a million [white] inhabitants of Detroit were Southerners who brought their prejudices, customs, and language with them. A black man was a "nigger"' (Widick, 1972:27). Large numbers of European immigrants quickly learned these southern traditions of race hatred.

History suggests that the presence of these southern whites, among whom support for capital punishment has been traditional, and the growing black population should have generated a death penalty (Platt and Takagi, 1977). The usual relationship between capital punishment and race has not been negated by harmonious black-white relations in the state. As early as the 1920s, the Ku Klux Klan was an important political power in Michigan. In the 1925 Detroit mayoral election, the KKK's candidate was defeated only by the technical invalidation of 17,000 votes (Widick, 1972). The population shifts mentioned above help explain a heated controversy in 1942 between blacks and whites regarding the possible racial integration of a new federally funded housing project (Capeci, 1984). Detroit set the bench mark for interracial violence during the riots of 1943 and 1967 (Boskin, 1969).

\section{Michigan Public Opinion}

Indeed, as might be predicted given the increasing crime rates and this volatile immigration mix, there has been steadily growing support for the death penalty in Michigan. Perhaps reflecting such changes, a 1952 prison riot in Jackson which involved guards being taken hostage triggered a bill calling for the execution of any prisoner convicted of murdering a guard (Lansing State Journal, 1952; 
Michigan HB, 482). After an especially horrible murder in 1950, a Detroit newspaper provided coupons in its paper. By mailing the coupons to the speaker of the Michigan house, readers could demonstrate support for a referendum on the death penalty. Two days later 2500 had been received (Detroit News, 1950b). This response suggested that many, perhaps a majority, of Michigan citizens supported the death penalty. By 1974 no speculation was needed. A survey found that 58 percent of Michigan residents favored capital punishment for murder (Bryant, 1974). As of 1976, 64 percent were in favor and by 1977, 72 percent agreed (Bryant, 1976, 1977). A 1978 survey in the Detroit area also found 72 percent favored executions of convicted murderers (Detroit News, 1978). In 1980, 67 percent of Michigan citizens favored executions for murder (Detroit News, 1980). In 1982 a 73 percent majority favored reinstitution of the death penalty in Michigan (Detroit Free Press, 1982b). By 1985, 77 percent of those surveyed supported capital punishment for murder (Detroit Newes, 1985b). All these figures parallel the growth in national support for capital punishment.

Surveys in Michigan in 1982 and 1985 also show that approximately two-thirds of Protestants and Catholics from all social classes supported reestablishing capital punishment (Crime in Michigan). Correspondingly, about two-thirds of whites in Michigan during 1980 supported repeal of the state's constitutional prohibition of capital punishment. Forty-four percent of Michigan blacks agreed (Crime in Michigan, 1980). Similarly, 44 percent of blacks in 1982 supported reestablishment of the death penalty (Crime in Michigan). Surveys in Michigan from 1974 to 1977 (Bryant) demonstrated that among blacks approximately half supported the death penalty for murder $(1974,51$ percent; 1975, 45 percent; 1976, 50 percent; 1977, 55 percent). Thus, in recent years surveys have shown that between two-thirds and three-quarters of whites and between 45 and 50 percent of blacks support a death penalty law for Michigan.

Given this swelling popular support, a death penalty statute should have been triggered in 1950 when a Michigan murderer:

told police he had gone out in the middle of the night to 'get me a woman'. He shot [a] father of four when [the victim] fought to protect his wife against the attack. 'I knew the most I would get was life in prison', the killer boasted after his capture. (Detroit News, 1950a: 24)

Nonetheless, Michigan, which in 1847 abolished the death penalty except for treason (Michigan Revised Statutes, 1846) and which at its 1962 Constitutional Convention abolished it for any crime by a lopsided 108 to 3 vote (Knapp, 1963; Michigan Constitution, 1963), has yet to pass a death penalty statute. This constitutional amendment was authored by the founder of a local special interest group, the Michigan Committee Against Capital Punishment. In any case, while continuing abolition in Michigan cannot be easily explained by conflict theory with its emphasis on oppression, the consensus orientation which holds that laws in democratic societies are a consequence of majority opinion is contradicted by survey data. Similar relationships between abolition and public opinion have characterized both Great Britain and the Federal Republic of Germany. Zimring and Hawkins (1986: 12) have noted that ' $[t]$ he inevitable progress of the abolition 
movement is all the more remarkable when the role of public opinion is examined. Successful and sustained abolition has never been a result of great popular demand.' Thus we are left with the puzzle that in some cases public opinion is reflected in local death penalty legislation, and in others it is not.

\section{Statement of the Problem: Symbolism of the Death Penalty}

The immediate purpose of this research is to isolate the cultural and political characteristics enabling Michigan's long-term death penalty abolition. An organization central to the continuing Michigan abolition, but by no means encompassing it all, was founded by a Republican in the early 1970 s as the Michigan Committee Against Capital Punishment. It was replaced in 1978 by a state-wide organization, the Michigan Coalition Against the Death Penalty. It is a singleissue organization composed of a heterogeneous mixture, including business, labor and civil liberties interests, the Michigan Bar, the State Trial Lawyers' Association, most churches and, in recent years, anti-abortion forces. Like its predecessor, this association also has Republican leadership. Here we will show how for approximately 150 years death penalty legislation has been successfully opposed, in recent decades by a powerful coalition which endures, in spite of escalating violence, economic decay, massive immigration into the state by southern whites and widespread popular support for capital punishment.

In a seminal study of the Woman's Christian Temperance Union (WCTU) movement and American alcohol prohibition, Gusfield (1955) noted characteristics relevant to such prohibitionist legislative efforts which he referred to as symbolic crusades. Symbolic crusades are so named because they symbolize the moral superiority of their proponents' way of life. For our purposes what is most significant is that those supporting national alcohol prohibition were successful for over a decade even while opposed by clear majority opinion. Evidence of similar culture conflict has been found in moral crusades as diverse as anti-pornography campaigns (Wood and Hughes, 1984; Beisel, 1990), antiabortion campaigns (Clarke, 1987) and campaigns for the banning of school textbooks (Page and Clelland, 1978). When compared with pornography and alcohol prohibition, or the banning of textbooks, the death penalty offers as good, or better, a candidate for analysis, given both the issue's longevity and the considerable symbolic significance of life, or more precisely of death. As a long-time observer of capital punishment has noted: 'The death penalty, today as in the past, symbolizes the ultimate power of the state, and of the government of society, over the individual citizen' (Bedau, 1987:246). If symbolic expression is ever sufficient to control the course of an issue, surely it would be in the case of capital punishment. ${ }^{1}$

\section{Arguments Against Capital Punishment}

Michigan's record of opposition to capital punishment is easy to verify. In 1844, seven years after Michigan became a state, a house select committee issued a 
majority report calling for the repeal of the death penalty. The report identified four objections to capital punishment. First, 'no man hath a power to destroy life but by commission from God the author of it' (House Majority Report, 1844: 2). Not only did the report claim the death penalty was not based on the Bible, but also that it slowed the trial process, could lead to the execution of innocent persons and was a mistake which could not later be reversed.

In 1865 the senate judiciary committee released a report on the death penalty which challenged its efficacy as a deterrent and concluded that capital punishment was not required by the facts of the existing situation:

The soldiers of our own revolution, although discharged and sent home half paid, and poorly clad, at a time when the country was embarrassed, the treasury exhausted, paper money depreciated, and the cost of living enormously high, like their great commander, quietly betook themselves to the pursuits of life, and it was remarked of them 'that the instances were rare where a veteran had returned to his home to disgrace it'. (Senate Judiciary Committee, 1865:5)

This historical fact was used to argue against the death penalty at the end of the civil war (Senate Judiciary Committee, 1865:3).

In 1929 arguments against a death penalty bill that passed both houses included the usual assertions that there was no proof executions deterred crime, capital punishment represented a step backward for civilization, the punishment was usually reserved for the poor and only a small proportion of murderers actually were executed (Journal of the Senate, 1929:639-40). One House member asserted: 'I am not in favor of any law which involves the taking of human life ... [which is] un-Christian ... uncalled for and ungodly ... a step backward in the onward and forward march of civilization' (Journal of the House, 1929:1171-3). During the capital punishment debate of the 1950s a University of Michigan professor argued that the death penalty reduced the certainty of punishment and therefore did not have the effect of producing lower serious crime rates (Flint Journal, 1955). Approximately twenty years later, a Michigan State University criminology professor was quoted as saying that executions do not stop homicides (Lansing State Journal, 1974b). In 1973 testimony before legislative hearings it was argued by a founder of the Michigan Committee Against Capital Punishment that the death penalty increased, rather than decreased, violence (House Hearings, 1973), and the long-term Republican opponent of the death penalty also stated that '[f]orty years of studies in America have shown that society is no safer with a death penalty' (Detroit Free Press, 1976a).

Lack of empirical evidence of deterrence has remained a keystone in the opposition to executions. The director of corrections in 1980 cited the lack of evidence of deterrence and the increased difficulty in getting convictions with the death penalty (Flint Journal, 1980). The head of the Michigan American Civil Liberties Union agreed (Michigan Chamber of Commerce, 1980), as did the Lieutenant Governor (Brickley, 1980). The United Auto Workers Union has been a powerful force in Michigan politics, and its opposition to the death penalty has been unwavering since the 1930s. This opposition is reflected in a 
1977 position statement: 'There is no evidence to suggest that Michigan's prohibition against capital punishment - in effect since the state was admitted to the Union 140 years ago - has contributed to the recent increase in the rate of homicide' (United Auto Workers, 1977:9). A newspaper column criticized a Florida execution and said that if the death penalty is truly a deterrent, then it should be carried out in a shopping mall or on television. Then people would 'be able to judge the effectiveness of what is supposed to be the ultimate deterrent against murder' (Detroit News, 1979a).

Delegates to the 1962 constitutional convention endorsed familiar reasons for rejecting the death penalty: executions are not a deterrent because serious offenses are a consequence of mental disturbance, the death penalty results in judicial delays and is biased against the poor and ignorant, the state sets a bad example for its citizens when it takes a human life, conviction of the innocent is possible and the death penalty is irrevocable (Knapp, 1963). This reasoning was obviously persuasive, for no arguments were presented against the provision for a constitutional ban on executions. As we will demonstrate, racism and racial discrimination inherent in the application of capital punishment are also frequently mentioned by Michigan's death penalty opponents. Thus, for over 100 years, Michigan opponents of the death penalty routinely have attempted to buttress their moral position with empirical fact. As impassioned as these arguments may seem, they have undoubtedly been used frequently in nonabolitionist states as well.

\section{The History of Death Penalty Prohibition}

What is unique about Michigan's early history is that so few executions took place. There exist records of eight executions in Michigan during the 1700 s by the French and British colonial governments (Burbey, 1938). Under the United States territorial authority, only three additional executions took place, two Native-Americans, Ketaukah and Kewabishkim in 1821, and Stephen Simmons in 1830. This suggests that opposition to the death penalty was in place well before statehood. Michigan's settlers had Puritan Yankee backgrounds and hailed from upstate New York and New England. They typically brought with them support of both the anti-gallows and anti-slavery movements (Bennett, 1978). Consequently, the death penalty was abolished, except for treason, in 1847. This sole provision for execution was never utilized.

Nonetheless, those few executed in Michigan reflect the same racial proportions as the massive number executed in southern states. 'Simmons', noted the Detroit Free Press (1960) 'is the only non-Indian ever executed by Michigan under American rule.' The execution of Simmons is important because the religious-revival atmosphere surrounding his execution created such revulsion in the audience toward capital punishment that it remains a part of Michigan's current capital punishment debate (Detroit Free Press, 1960; Lansing State Journal, 1972a). As recently as 1977 a Michigan paper mused: 'One thing is certain, all through the coming months of debate, Stephen Simmons will be living 
again along with each morbid detail of his fatal plunge through the gallows' trap door' (Lansing State Journal, 1977). A law professor in Michigan referred to this execution and noted in an interview that 'the real action against capital punishment took place after a white male who had killed his wife in a drunken condition was executed in Detroit'. The reaction to the execution of Stephen Simmons created much more outrage than did the execution of the two Native-Americans before him. The 1837 execution of Patrick Fitzpatrick, even though he was actually put to death in nearby Canada, is also remembered in Michigan because shortly after his execution another person confessed to the crime. The last person executed in Michigan was Anthony Chebatoris who was put to death in 1938 by federal authorities. His execution was described as 'distasteful' (Detroit News, 1959; see also Detroit Free Press, 1958), and was carried out over the objection of the Michigan governor (Detroit Newes, 1959).

\section{Michigan Political Leaders and Capital Punishment}

Michigan is unique in that most of the state's political and religious leaders traditionally have opposed the death penalty. In vetoing a 1929 death penalty bill the governor said: 'We put rich men in prison but when it comes to electrocuting them it simply would not be done. ... Juries would be very slow to render a verdict that meant a mandatory sentence of electrocution' (Journal of the Senate, 1929: 1142-3). In 1931 there was a different Michigan governor, but one with the same opinions as his predecessor. The new governor called that year's death penalty bill 'warfare on the individual' ('Capital Punishment' n.d.: 3). It was opposed by former governors, most judges, and even Henry Ford ('Capital Punishment' n.d.). At that time the Michigan Federation of Labor called the bill a 'law of the rich and relic of the past' ('Capital Punishment', n.d.: 3).

In 1946 the Michigan director of corrections opposed such a law (Lansing State Joumal, 1946), as did the corrections director in a 1985 interview. The latter cited racism as inherent in support for the death penalty. The Michigan Bar has been opposed to the death penalty, stating in 1985 that the state 'should not become a brutalizing agent' (Lansing State Journal, 1985b). As early as 1945 a newspaper observed that a majority of the house 'has had enough "legalized murder" legislation' (Grand Rapids Press, 1945). Later another warned:

\footnotetext{
When emotion and not logic rules the administration of justice, we are well on the way to losing sight of justice and of our own claim to civilization. The people of Michigan recognized that dark pit nearly a century and a half ago, and wisely stepped back from the brink. We urge them to exercise the same wisdom. (Saginaw News, 1980)
}

In 1984 a state representative who favored the death penalty limited his legislative proposal to those convicted of killing police officers. He argued: 'I know what the feeling of the people is, and the leaders of the state, and its taboos on the death penalty. I'm trying to establish a beachhead. Maybe this might have a chance' (Gongwer News Service, 1984). 
A former director of corrections noted in an interview that prior to the civil war Michigan was an underground railway terminal for escaping slaves on their way to Canada (see also, Lincoln, 1987). Paralleling the nineteenth-century opposition to slavery that was linked to forces arrayed against capital punishment, racism associated with the south has for over a century been opposed by Michigan's cultural practices. The editor of the Detroit Free Press noted that both black and white southerners have a history of violence and 'if you create a system where life is cheap, the people will see life as cheap'. A co-chair of the Michigan Coalition Against the Death Penalty in an interview noted there was little southern immigration until the Second World War and the 'south favors the killing ethos. Earlier Michigan was spared these people who were for capital punishment.' As a case in point the Detroit Free Press (1985a) noted that the first-term senate sponsor of a 1985 Michigan death penalty bill was a graduate of the fundamentalist Bob Jones University in South Carolina. The senator was quoted as saying that 'Government has a responsibility to use its authority to punish the wrongdoer. When it [the Bible] talks about the power of the sword, it shows it certainly has the authority and obligation to use the death penalty, as a government' (Detroit Free Press, 1985a: 10A).

An amendment proposed for a 1929 death penalty bill called for $\$ 25,000$ to be paid by the state to the heirs of any person executed and later found to be innocent, emphasizing the degree of concern about such accidents (Journal of the House, 1929). This proposal was tried again in 1931 with the stipulated payment reduced to $\$ 5,000$ (Journal of the House, 1931:249). In 1953, a derisive amendment to a death penalty bill called for execution by stoning to death on the steps of the Capitol building (Lansing State Journal, 1953). More recently, a senator who opposed the death penalty was quoted as sarcastically suggesting that if the citizens of the state reinstated the death penalty, they should be required to provide the executioners which would be selected by lot from the general population (Detroit News, 1985a).

In 1871 a petition on behalf of eighty-seven ministers, deacons and elders of the True Dutch Reform Church, asking for a return of the death penalty, was delivered to the Michigan House (Kohler, 1980). During the twentieth century, however, the Michigan Council of Churches, along with other major organized religious groups, generally have opposed capital punishment. Roman Catholic clergy through the 1940s and 1950s at times publicly supported executions (for example, see Catbolic Weekly, 1959). Later, however, this began to change. Perhaps spurred on by the 1973 Roe v Wade US Supreme Court decision increasing access to legal abortions, the Catholic Church rethought its position on capital punishment. A 1985 policy noted that

[f]or more than a decade, the Michigan Catholic Conference, the voice of the Catholic Church in Michigan in matters of public policy, has opposed efforts to institute the death penalty in our state. This position has always been onelinked to the Church's respect for human life in its diversity of circumstances - born and unborn.

The Roman Catholic Church's concept of being pro-life was described by a member of the clergy as a 'seamless garment'. Accordingly, the taking of a human life is never acceptable (Senate Judiciary Committee, 1985). 
Thus, in Michigan the death penalty has been characterized as barbaric and racist, an attack on the poor and the innocent, linked to abortion and contrary to Christian dictates. Therefore, those who demand this detestable practice should be compelled to implement it, should be financially accountable for errors in its application and should be forced to observe it in its most brutal form. All of these claims make a clear and forceful case for the moral superiority of abolition. Also, through the decades it has been observed repeatedly that the death penalty cannot be reversed in the case of judicial error. The idea that the death penalty may be a deterrent has been rejected by Michigan elites for at least 150 years, long before any statistical evidence was available, a position taken by Michigan governors, lieutenant governors, several directors of corrections, US senators and representatives, state senators and representatives, judges, the Michigan Bar, the Michigan Council of Churches and the Michigan Catholic Conference.

\section{Characterization of Death Penalty Supporters in the Press}

Consistent with the early association of the death penalty with slavery, in the Michigan press, race, racism and the deep south are associated with supporters of capital punishment (Detroit Newes, 1981b). A columnist pleaded: 'Put away those varnished electric chairs, human gas chambers and cyanide pellets, rifles aimed at hearts, and the latest device - the intravenous "humane" poisoning equipment which looks like it belongs in a Nazi death camp' (Detroit News, 1981a). The Detroit Free Press, in 1981 published statistics compiled by the National Association for the Advancement of Colored People which showed most death row prisoners were in the south; 150 in Florida, 137 in Texas and 97 in Georgia. The Detroit Newes reported in 1983 that there were 1050 on death rows in the United States, the largest in history. More than two-thirds of this population were in southern states. Blacks accounted for 40 percent of death row inmates.

Supporters of the death penalty were often presented as crude and unfeeling. In 1979 the father of a murder victim who started a petition drive to place the issue of reinstatement on the general election ballot said that executions did not eliminate a human life of those condemned since 'they're subhuman' (Detroit News, 1979b). A senator argued that the death penalty was required to strike back at 'mad dogs' (Lansing State Journal, 1970). The wife of a slain Michigan state highway patrol officer who helped lead a 1982 petition campaign was pictured shortly after her initial involvement in both the Detroit News, (1982a) and the Detroit Free Press (1982a) wearing a 'Fry 'em in Michigan' T-shirt while collecting petition signatures. She expressed regret: 'It's a funny shirt if you're wearing it around friends, but I wish I had never put it on. People won't understand' (Detroit Free Press, 1982a).

A sponsor of a house death penalty resolution noted defensively that ' $[i] \mathrm{t}$ was said in committee that this is a racist proposal, that it's aimed at black people. But I'd like to point out that it's not' (Detroit Newe, 1973a). In making this point she observed that the killers of both President Kennedy and Martin Luther King 
were white. The primary Michigan advocate of capital punishment during the 1970 s was a state senator described in the Lansing State Journal as 'A hard-line conservative ... who in 1972 switched from Democrat to Republican on the basis of the school busing issue' (Lansing State Journal, 1973). His reaction to capital punishment statistics showing a bias against blacks was: 'It does seem minorities kill more than others. That does not excuse them at all' (Detroit Free Press, 1985b: 15A). Thus, in the senator's view the death penalty was not racist. Blacks simply behave worse than whites and deserve what they get. The senator was also quoted in the Detroit Free Press (1976b) as saying: 'We're talking about putting away an animal'. He also indicated that he could execute a first-degree murderer. According to the senator capital punishment was similar to hunting, or killing with a purpose (Lansing State Journal, 1974a).

During the 1980s this senator was succeeded by a county prosecutor as the primary moving force in the quest to reestablish capital punishment in Michigan. Like the senator, the prosecutor was allegedly elected on the strength of his association with opposition to school busing to achieve racial balance (Detroit Free Press, 1984). On the death penalty he was quoted as saying: 'I've buried three police officers. I'm tired of it. I'm telling the punk murderers, if you take a life we may damn well take yours' (Lansing State Journal, 1980). An article responded to such anger by quoting a death penalty opponent as follows:

During the debate over busing, the code word was that busing was 'impractical'. But let's face it - what people really meant was they just didn't want racial mixing. Capital punishment used to be the same way. People could hide their real feelings by saying, 'its a deterrent, its good for society'. Now there's less reluctance to say, 'Fry the bastard, he deserves it'. (Detroit News, 1981b: 8A)

A cartoon appearing in the Detroit Newes (1982b) depicted the prosecutor being lifted into the air by balloons while seated in an electric chair, suggesting that he was a demagogue, using the death penalty for personal gain. The caption read, 'Capital Punishment - It's a Real Crowd Pleaser'. In an interview the acting director of the state department of corrections indicated that the prosecutor was 'looking for something to ride into office'. In 1984 the Detroit Free Press also cast a cynical eye on the career of this prosecutor in an article titled 'Capital Punishment and Capital Ambitions'. The paper's editor observed 'If Michigan has a demagogue - he would be it'.

A Lansing State Journal article reviewed southern executions through the critical eyes of a Texas editor who had witnessed the incredible total of 189 executions (Lansing State Journal, 1972b: 1C). The Detroit Nezes noted that in Florida demonstrators against a 1981 execution were mocked by a group which displayed a model electric chair, nicknamed Sparky, chanting 'go Sparky go' (Detroit News, 1981b:1A). In testimony before the Michigan senate judiciary committee a local attorney, and member of the Michigan Coalition Against the Death Penalty, recalled another execution in Florida.

They were in the process of [an execution and] ... the Jacksonville police were out en masse at the prison. They were lined up, all wearing T-shirts with an electric 
chair on them, saying, 'kill, kill, kill'. After the execution, and the hearse went by, they cheered. It was chilling. (Senate Judiciary Committee, 1985)

In Alabama the attorney general was elected after promising to "fry" convicted murderers until smoke comes out of their ears' (Detroit News, 1981b:1A). Virginia was derided in a cartoon depicting an execution there involving an electric chair and a large hooded executioner with 'Virginia is for Lovers' written on his chest (Detroit News, 1982c). Later, Michigan representative John Conyers petitioned Virginia's governor to block the scheduled execution of a retarded prisoner in that state. The governor refused (Detroit Free Press, 1985c). Lester Maddox, the lieutenant governor of Georgia, described the United States Supreme Court Furman decision, which halted all executions in 1972, as 'a license for anarchy, rape and murder' (Detroit News, 1972). All of these press discussions characterized supporters of the death penalty as being very crude.

\section{Isolation of Officials Supporting Capital Punishment}

Because of these negative connotations, very few legislators actively support capital punishment bills. For example, during house committee hearings in 1951, in addition to the bill's sponsor, only two spoke on behalf of a death penalty bill (Detroit Newes, 1951). None spoke at the 1962 constitutional convention against the revision abolishing the death penalty (Knapp, 1963). Even the Fraternal Order of the Police in 1978 did not formally endorse capital punishment. They limited their support to putting the issue on the ballot (Detroit Free Press, 1978). After some initial confusion in 1976, the Michigan Chamber of Commerce claimed not to be officially in favor of the death penalty (Detroit Nezes, 1976a). As the long-time leading senate death penalty supporter observed in an interview: 'It is easy to get people to speak against capital punishment, but hard to find people to speak in favor of it'. He said people would not sign a referendum petition in 1974 because signing their names was somehow different from stating personal opinions. (This could offer an explanation for opinion surveys showing solid popular support for reinstatement of capital punishment and the repeated failure of petition efforts.)

Echoing the senator's experience, the prosecutor who took over leadership in the efforts to restore the death penalty was nearly alone in his crusade. Thus, he felt it necessary to make three to four speaking engagements per week on behalf of the referendum issue (Lansing State Journal, 1980). Failure to establish state-wide support for capital punishment moved the prosecutor to promise to launch a new petition drive for the 1984 ballot only if elected state attorney general (Lansing State Journal, 1982). This condition was abandoned after he was defeated, for he nevertheless revived his death penalty crusade. Even though capital punishment was endorsed by the 1985 state Republican convention, individual Republican candidates were not forced to endorse capital punishment, and the prosecutor was the sole person to speak in favor of the death penalty at the convention (Lansing State Journal, 1985a). A Michigan State professor 
observed that the failure of a 1982 petition could be explained by the fact that no political organization supported it. 'The petition had no circulation and it died.' Political leaders and the press have vilified and isolated those bold enough to announce their support for capital punishment. Thus we see a clear marginalization of Republican death penalty advocates which makes election in state-wide races impossible, and consistent with this it also appears that only already marginalized politicians in Michigan willingly offer public support for death penalty initiatives.

\section{Efforts to Reinstate the Death Penalty in Michigan}

In 1985, during consideration of a death penalty bill, testimony before the senate judiciary committee noted that from 1930 to 1985,49 percent of those executed for murder were black, as were 76 percent of those executed for robbery and 91 percent executed for rape. Whites accounted for 75 percent of commutations and 80 percent of the reversals on appeal. It was claimed that, as of 1985 , blacks made up 52 percent of homicide victims, but only 13 convicted killers were on death row for killing blacks. 'The fact is that a black life is worth less than a white life in our society' a witness at senate hearings asserted (Senate Judiciary Committee, 1985). Another witness testified that while blacks make up only 12 percent of the United States population, 57 percent of the condemned were black. A Lansing State Journal (1946) article noted Michigan's one hundredth year without capital punishment. An international movement away from the death penalty was noted in 1957 (Lansing State Journal, 1957). Both Canada and England were struggling with an issue that Michigan had resolved 117 years ago, according to a local paper (Detroit Newer, 1964). A death penalty opponent noted that Michigan was the first English-speaking government to abolish capital punishment (House Hearings, 1973). One hundred and twenty seven years of abolition in Michigan were also noted (Lansing State Journal, 1974a). A Detroit public defender testified during Michigan senate hearings in 1985: 'Why kill when you [Michigan] have shown the world for 140 years that there is an alternative? You can read in other languages all over the world "Michigan" because it was the first government to abolish the death penalty' (Senate Judiciary Committee, 1985).

A state senator claimed: 'The Michigan constitution has served as an example to many societies and to other states as kind of a leading light in the nineteenth century when capital punishment was still very, very much prevalent' (Journal of the Senate, 1985:1129). In an interview in 1985 the editor of the Detroit Free Press said that in Michigan a 'tradition exists that worries about social justice'. Soon afterwards, in another interview, the dominant senate supporter and sponsor of numerous capital punishment bills challenged this view of Michigan history:

The media allows Michigan to con itself. Capital punishment was not abolished in Michigan. A person was hanged and later it was found he was not guilty, so the 


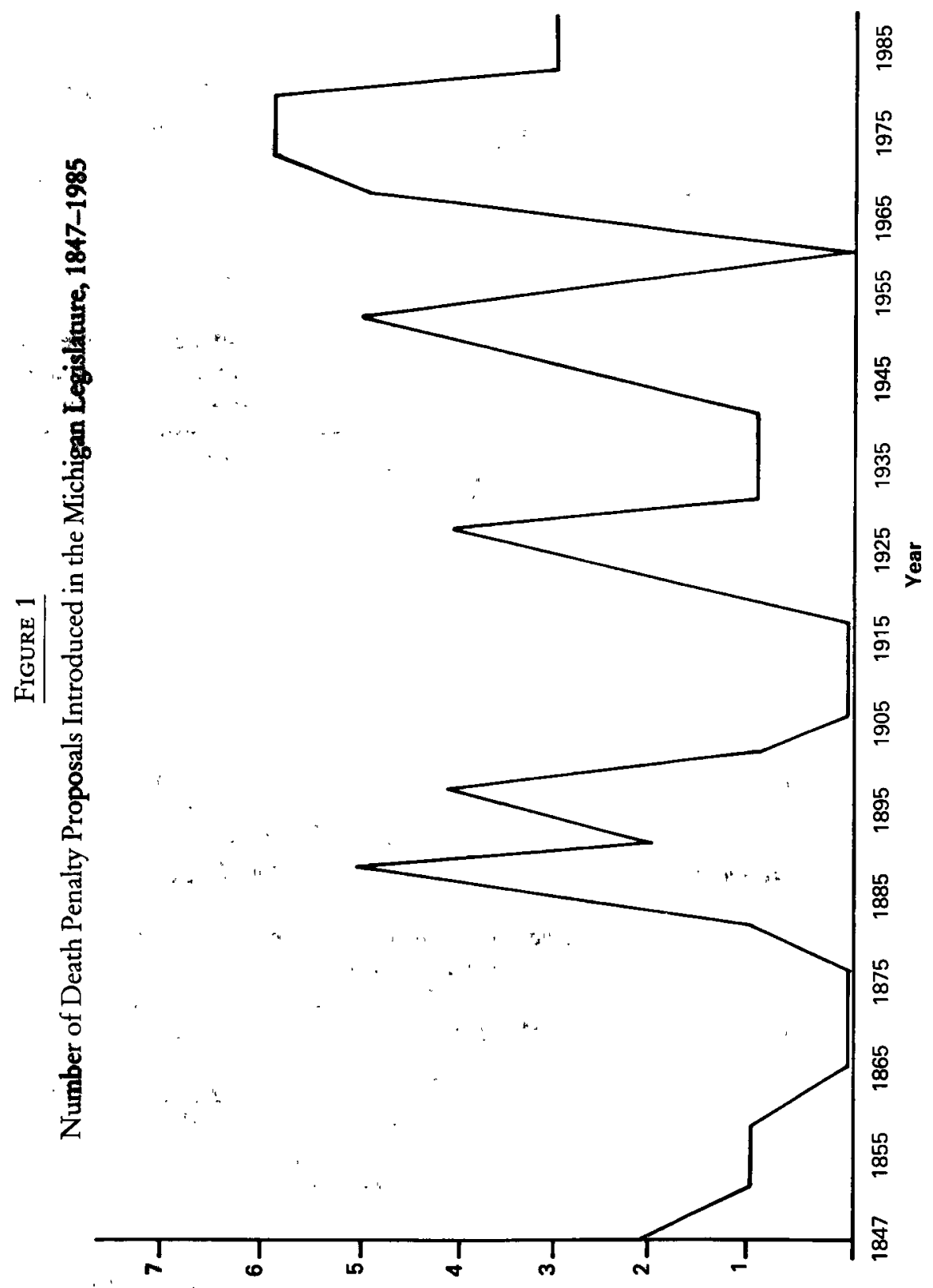


legislature prohibited, not abolished capital punishment. If we truly abolished, then it would be a shame to go back.

This tortured reasoning is that since the state of Michigan has not executed anyone since statehood, the state cannot abolish something that it has never actually used. The state, according to this senator, was the first to prohibit and forbid the death penalty but not the first to 'abolish' it. This strained logic reflects the important role that the history of abolition plays in its maintenance. This history is frequently noted in the press and mentioned by opponents of the death penalty (Lansing State Journal, 1967, 1974b, 1975; Detroit News, 1976b, 1984). Frequent reference by the press to this history of abolition coexists with widespread editorial opposition to capital punishment.

Nevertheless, between 1846 and 1985 there were sixty-two legislative (Figure 1) and four petition attempts to reinstate the death penalty. Figure 1 demonstrates that the amount of legislative activity has increased in recent years as has the murder rate. Since 1973 there has been a nearly continuous effort to reinstate the death penalty through four initiative petitions. The first petition effort began in 1973 and lasted into 1974, the second was from 1976 to 1978, the third from 1979 to 1982 and the fourth began in 1982 and ended in 1986. The frequency and intensity of legislative and petition proposals clearly have increased since the 1960s. As the frequency of these initiatives increased the press predictably gave more editorial attention to this issue. An admittedly non-exhaustive and non-random collection of newspaper editorials found in government files dating back to 1950 was compiled, together with all editorials from the Detroit News during the period 1976-85. These statements suggest that death penalty editorials have, since 1975, become both much more common and, since 1980, increasingly opposed to such legislation (Table 1).

TABLE I

Michigan Newspaper Editorials' Position on Capital Punishment, 1950-1985

\begin{tabular}{lccc}
\hline Year & \multicolumn{3}{c}{ Capital Punishment Position } \\
\cline { 2 - 4 } & Positive & Neutral & Negative \\
\hline $1950-54$ & 0 & 0 & 0 \\
$1955-59$ & 1 & 0 & 0 \\
$1960-64$ & 0 & 0 & 1 \\
$1965-69$ & 0 & 0 & 0 \\
$1970-74$ & 1 & 1 & 1 \\
$1975-79$ & 10 & 5 & 10 \\
$1980-85$ & 7 & 2 & 21 \\
\hline
\end{tabular}

In 1929 the Michigan governor vetoed a death penalty bill and demanded instead a bill that called for a statewide referendum:

If a bill ever justified a referendum this is the bill. It legislates on a subject on which most people have fixed opinions, and it is so drastic that it will never work out 
unless there is strong public sentiment in back of it. (Journal of the Senate, 1929: 1142-3)

In 1931 when a death penalty bill last passed both houses, opponents of the death penalty had such trust in popular opposition that they supported the bill on the condition that it contain a referendum clause, while the sponsor of the bill bitterly opposed a referendum (Lansing State Journal, 1931). A state-wide referendum proposing the death penalty was held that year. It failed by a 352,594 to 269,538 vote (Journal of the Senate, 1931:1278). Retaining this strategy, death penalty opponents attached a referendum to a 1943 death penalty bill (Journal of the House, 1943). In 1947 supporters of the death penalty remained suspicious of public opinion and thus were opposed to a referendum clause being attached to the legislation (Detroit News, 1947). In 1951 two opponents of a death penalty bill introduced a resolution on capital punishment requiring a referendum but withdrew support for it after a bill lacking a referendum clause failed in the House (Detroit Free Press, 1951). A supporter of yet another death penalty bill in 1952 was opposed to a referendum amendment (Lansing State Journal, 1952).

By 1973, however, death penalty supporters both in and outside of the state legislature viewed public opinion as an ally. Consequently they started an initiative petition calling for a referendum on the death penalty (Detroit News, $1973 \mathrm{~b}$ ). The petition effort failed to secure the necessary number of signatures to put capital punishment on the November 1974 ballot. The effort netted only 180,000 of the 265,000 signatures required (Detroit Neres, 1974). In 1976 another petition drive was initiated. This effort failed by 17,000 signatures (Lansing State Journal, 1979). In 1979 yet another petition drive was begun by the father of a thirteen-year-old female murder victim (Detroit News, 1979b). Although the necessary number of signatures was delivered to the secretary of state, many of the petition signatures were found to be invalid by the state election board, after a challenge by the Coalition Against the Death Penalty. Thus, capital punishment did not appear on the 1982 ballot (Detroit News, 1982d). In 1984 yet another petition effort to put the death penalty question on the 1986 general election ballot was begun, but as in 1982 many petition signatures were declared to be invalid, this time because they were judged to be over 180 days old, a violation of state referendum legal requirements (Michigan Public Act 112, 1973; Department of State, 1986). These events demonstrate that it is very difficult to get public support for death penalty initiatives among citizens given the obvious opposition in the press and among politicians. The director of the Michigan Council on Crime and Delinquency observed: 'If people in this state were really into capital punishment they would sign petitions.'

Increasing numbers of legislative and petition efforts give the impression that Michigan has been gradually moving closer to a death penalty. But in fact a death penalty bill passed both houses of the state legislature only in 1929 and 1931, and a single referendum was submitted to the voters in 1931. An effort in 1973 to allow a full house vote on the death penalty by discharging it from committee (Committee on Constitutional Revision and Women's Rights) was defeated by fifty votes to fifty-six. In the first full senate vote since 1931, a Republican 
controlled senate could muster a total of only six votes in favor of a 1986 death penalty resolution. Moreover, the 1963 state constitutional prohibition actually made reestablishment considerably more difficult. Constitutional prohibition requires either a two-thirds vote of both legislative houses followed by a majority vote of the electorate, or a successful initiative petition drive putting the issue on the ballot followed by a majority vote of the electorate which would then allow, but not require, the legislature to reinstate capital punishment. In reality, there is no evidence that Michigan has been on the verge of reinstating the death penalty. A leading Republican opponent of the death penalty noted in a 1985 interview that the constitutional prohibition was passed in recognition of shifts in public opinion and was designed to make legislative expression of this opinion more difficult.

\section{The Contradiction of Traditional Elite Resistance to Capitai}

\section{PUNISHMENT}

By the time Michigan first experienced significant population heterogeneity there had been no death penalty in Michigan for nearly a century. Murder rates did not dramatically escalate until the 1960s. Thus early Michigan history provided an environment conducive to the development and maintenance of abolition, not unlike that in other early abolitionist states. It has been noted that once abolition laws are in place the tradition of abolition develops a power of its own. Zimring and Hawkins (1986) note, for example, that states that had no death penalty prior to the Furman decision, typically did not pass one later and that those with a death penalty prior to this decision, also passed one later. The influence of tradition is recognized by those on both sides of the abolition debate in Michigan. Nonetheless, a general theory of legislative tradition does not adequately explain the Michigan situation. Contrary to Zimring and Hawkin's contention that in abolitionist states support for capital punishment decreases over time, the support for capital punishment reflected in public opinion polls has never been greater in Michigan.

Thus, continued abolition through the second half of the twentieth century is more difficult to explain. There is no indication that unique characteristics of the organization of the state legislature account for its frequent rejection of death penalty bills. There is no evidence, for example, that key committee chairs have been responsible for blocking death penalty bills in committee and thereby preventing them from reaching a vote in the legislature. Rather, legislative leadership has been relatively united in opposition to reestablishing capital punishment, just as Bruxton (1973:244) has observed in England where 'in the case of capital punishment, legislators still lead from the front'. Yet political leaders in Michigan have not had to operate alone. The assistance of the mass media is an especially important part of the equation for the 'news is an ally of legitimated institutions' since unlike politicians, 'the "average" man or woman does not have such access to the media' (Tuchman, 1978:4). Thus reporting helps maintain the status quo. In this way the media's effects on the political agenda are 
by 'magnifying movements that have already started, as opposed to originating those movements' (Kingdon, 1984:63). The press has largely controlled the nature of public discourse on the issue of capital punishment. It has contributed to the definition of capital punishment as uncivilized and racist, making public support for reinstatement very difficult. Many citizens appear reluctant to sign initiative petitions and the few politicians who endorse capital punishment have short and unsuccessful careers.

Moreover, there has been a near unanimous rejection of capital punishment by the leaders of religious, labor and professional organizations. This elite preference for less coercive statutes is consistent with the observation that to 'the extent conflicts of attitudes become widespread in contemporary American society, it is dominant groups that are more likely to endorse the more tolerant viewpoints' (Hagan et al., 1977:321-2). Similarly, Zimring and Hawkins (1986: 155) have noted that considering that the legal and medical professions have largely opposed capital punishment 'there is a tradition of deference to the organized legal and medical professions in matters of moral judgment that might be influential and exploitable in this connection'. Bedau (1987:137) indicates how a wide range of elites are involved in the abolition movement in the US even though they have nothing personal to gain from such activity and the direct beneficiaries of abolition are the 'lumpenproletariat of America: the poor, the nonwhite, the uneducated, the unemployed'. Yet the alleged altruism of these elites seems inconsistent with their positions on other related issues.

\section{THE CONTRADICTION RESOLVED}

Many observers have noted that on the issue of capital punishment elites often put benevolence above class interests. The question remains whether this Michigan elite opposition to capital punishment spills over into other criminal justice policy. Helfman (1956) argues that from 1847 to 1861 convicted murderers in Michigan were treated more cruelly than if they had been executed. They were sentenced to life in solitary confinement at hard labor. Worse yet, labor was never provided, and visits were restricted to prison staff and any visiting clergy. In 1859, for example, four of the twenty-two lifers died and three became insane. Prison personnel estimated that eight years of 'unmixed suffering and misery' was the average life expectancy of persons sentenced to solitary confinement. Even more recently there has been some questioning of the humaneness of Michigan's criminal justice system. In 1987 the state ranked fifteenth in the percentage of its citizens imprisoned (Austin and Brown, 1989). A ratio based on the 'total index crime rates' compared with 'total control rates' placed Michigan thirteenth in punitiveness. Studies of the state's massive state prison in Jackson ranging from the 1950s to the 1980s describe it as among the worst in the nation (Martin, 1954; Dilulio, 1987).

The isolation of Michigan's abolition from other portions of the state's criminal justice policy suggests that there is not necessarily any contradiction between abolition and elite class interests. The elites' alignment with religious 
leaders on this cause serves to dramatize the moral superiority of the status quo. Edelman (1964) has observed that elites have often endorsed humane and progressive legislation in an effort to protect their economic self-interests. More specifically, others have noted (Rusche and Kirchheimer, 1939; Adamson, $1983,1984)$ that historically, when elites have opposed the death penalty in favor of imprisonment, it was rooted in their economic interests, even if justified by them on moral grounds (Orland, 1975). Correspondingly, Foucault (1977) has argued, humane penal reforms that rejected torture and death in favor of imprisonment and rehabilitation have obscured, and thereby helped protect, the coercive and repressive nature of the existing social and economic order. In considering executions Foucault reasoned that 'a confused horror spread from the scaffold; ... [I] $t \mathfrak{t}$ was always ready to invert the shame inflicted on the victim into pity or glory, it often turned the legal violence of the executioner into shame' (Foucault, 1977:9). Even as early as the eighteenth century many began to 'doubt the efficacy of [the ritual of] public hanging as a deterrent' to crime and instead recognized that this practice seemed to generate disrespect and defiance of law in general (Ignatieff, 1978: 23). Thus, all of these writers have broken the connection between crime and punishment, relating punishment instead to social structure. Such an explanation does not contend that Michigan's abolitionists were necessarily motivated by punitive sentiments. The abolitionist coalition is heterogeneous and motivations vary. Even so, the perceptual significance of abolition may extend beyond criminal justice. As with any symbolic legislation the audience of the law is a significant consideration. In this case it appears that the elite abolitionists not only attempt to convince others of their general moral virtue, but in so doing they appear to have convinced themselves.

Whatever the motivations involved, it must be said that there is much to admire in Michigan's continuing abolition of capital punishment. The leaders in the state clearly recognize the irony of a democracy adopting a legal practice identical to that found in murderous dictatorships such as South Africa, China and Iran. Among western industrialized democracies, only the United States kills its own citizens. Michigan leaders hold out against a growing tide of executions elsewhere in the nation. Between 1977 and 1991 there were 157 executions in sixteen American states. Considering that by the end of 1991 an additional twenty states had laws that provided for capital punishment, most observers expect that the pace of executions will soon quicken. By the end of 1991 a total of 2482 prisoners were under sentence of death in the United States (US Department of Justice, 1992).

\section{Notes}

Communications should be sent to John F. Galliher, Department of Sociology, University of Missouri, Columbia, MO 65211. The authors are grateful to Howard Becker, Gideon Sjoberg, Ted Vaughan, Michael Radelet, J. Kenneth Benson, Donald Granberg and Richard Quinney for guidance and support in pursuing this research. An earlier 
version of this paper was read at the annual meetings of the American Sociological Association, Atlanta, Georgia, August 1988.

1. Data Sources: Data for this study were gathered from personal interviews and existing documents. Leading death penalty opponents and supporters were identified for interviews through news reports. Once a set of names was identified, additional persons were added by 'snowball' sampling. Persons interviewed were asked to suggest additional names of knowledgeable respondents. Those interviewed included members of the state legislature, journalists, prosecutors, two former directors of the state department of corrections and college professors. This research was aided immeasurably by an unpublished history of early Michigan abolition written by Thomas Kohler (1980) while he was a law student at Cooley Law School in Lansing, Michigan. His manuscript provided a valuable basis of comparison with this analysis. We also used the following existing sources: (1) proposed Michigan death penalty legislation from 1947 to July 1985; (2) Michigan house and senate journals from the first state legislative session in 1835-1836 to July 1985. These journals provide a record of the progress of all legislative bills; (3) reports of the Michigan Legislative Service Bureau, which is responsible for writing bills and conducting background research on proposed legislation; (4) house and senate floor debates; (5) records of house and senate committee hearings; (6) publications of the Michigan Department of Corrections; (7) legislative recommendations of the United Auto Workers labor union; (8) the Michigan Report, a publication of the Gongwer News Service, was available from 1962 to July 1985 indicating the progress of legislation; (9) the State Library's file on the death penalty with newspaper clippings from 1950 to 1985 primarily from the Detroit News, the Detroit Free Press and the Lansing State Journal; (10) all death penalty articles appearing in the Detroit Neres between January 1976 and March 1985.

\section{REFERENCES}

Adamson, Christopher, R. (1983) 'Punishment after Slavery: Southern State Penal Systems, 1865-1890', Social Problems 30: 555-69.

Adamson, Christopher R. (1984) 'Toward a Marxian Penology: Captive Criminal Populations as Economic Threats and Resources', Social Problems 31: 435-58.

Austin, James and Marci Brown (1989) 'Ranking the Nation's Most Punitive and Costly States', Focus (National Council on Crime and Delinquency, July).

Bedau, Hugo A. (1982) The Death Penalty in America, 3rd edn. New York: Oxford University Press.

Bedau, Hugo A. (1987) Death is Different: Studies in the Morality, Law, and Politics of Capital Punishment. Boston: Northeastern University Press.

Beisel, Nicola (1990) 'Class, Culture, and Campaigns Against Vice in Three American Cities, 1872-1892', American Sociological Review 55: 44-62.

Bennett, Edward W. (1978) 'The Reasons for Michigan's Abolition of Capital Punishment', Michigan History Magazine 62: 42-55.

Boskin, Joseph (1969) Urban Racial Violence in the Twentieth Century. Beverly Hills, CA: Glencoe Press.

Brickley, Lt. Governor James H. (1980) Press Release, (2 February).

Bruxton, R. J. (1973) 'Criminal Law Reform: England', American Joumal of Comparative Law 21: 230-44.

Bryant, Barbara (1974-77) Michigan Public Speaks Out on Crime, edns 1-5. Market Opinion Research, commissioned by Michigan Executive Office, Detroit. 
Burbey, Louis H. (1938) 'History of Execution in What is Now the State of Michigan', Michigan History Magazine 22: 443-57.

Capeci, Dominic, Jr (1984) Race Relations in Wartime Detroit. Philadelphia: Temple University Press.

'Capital Punishment' (n.d.) unpublished pamphlet, Michigan State Library.

Catholic Weekly (1959) Question Box (7 June).

Clarke, Alan (1987) 'Moral Protest, Status Defence and the Anti-abortion Campaign', British Journal of Sociology 38: 235-53.

Crime in Michigan (1980, 1982, 1985) Detroit: Market Opinion Research.

Department of State (1986) Michigan Interoffice Memo (11 September).

Detroit Free Press (1951) 'Death Penalty Referendum Plans Drawn' (25 Jan.).

Detroit Free Press (1958) 'Tony Chebatoris Failed in All Things - Except Keeping a Date with Hangman', (28 Dec.).

Detroit Free Press (1960) 'The Age-Old Question - Tooth for a Tooth?' 20 March: 1D, $6 \mathrm{D}$.

Detroit Free Press (1976a) 'Foes Insist Death Penalty No Crime Cure' (11 Dec.).

Detroit Free Press (1976b) 'Legislators, Police Join in Campaign for Death Penalty', (15 Dec.).

Detroit Free Press (1978) 'Police Join Drive for State Vote on Death Penalty' (1 Feb.).

Detroit Free Press (1981) 'U.S. Death Row Population up 20\% in a Year' (8 March): $14 \mathrm{~A}$.

Detroit Free Press (1982a) 'Slain Trooper's Widow Wears "Fry em" Shirt' (18 March).

Detroit Free Press (1982b) 'Michigan Voters Support Death Penalty, Poll Says' (13 Aug.): $1 \mathrm{~A}, 2 \mathrm{~A}$.

Detroit Free Press (1984) 'Capital Punishment and Capital Ambitions' (21 Oct.): 7, 10, 12.

Detroit Free Press (1985a) 'Senate Panel May Call for a Return of Death Row' (27 May): $3 \mathrm{~A}, 10 \mathrm{~A}$.

Detroit Free Press (1985b) 'Senate Panel OKs Death Penalty' (29 May): 1A, 15A.

Detroit Free Press (1985c) 'Friendship with Killer Broke Every Stereotype' (27 June): 1A, $7 \mathrm{~A}$.

Detroit Newes (1947) 'Death Penalty Up to Senate' (7 May).

Detroit News (1950a) 'Williams Bars Way for Bill to Provide Death for Slayers' (18 June): $1,24$.

Detroit News (1950b) 'Petitions “Amaze" Legislator: Demands for Death Penalty Mounting' (22 June): 1, 2.

Detroit News (1951) 'Death Penalty Bill Doomed' (23 Feb.).

Detroit Neres (1959) 'How One Bandit Died' (27 Jan.).

Detroit Nezes (1964) 'Capital Punishment-State Keeps Eye on Its Slow Death' 27 Dec.): $14 \mathrm{C}$.

Detroit News (1972) 'High Court Leaves Door Open - Slightly: New Capital Punishment Laws?' (30 June).

Detroit News (1973a) 'Death Penalty Bill Fails to Clear House Unit' (6 April).

Detroit News (1973b) 'Petition Drive Underway: Death Penalty Sought in State' (2 Aug.).

Detroit News (1974) 'Capital Punishment Bill Dead' (19 June).

Detroit News (1976a) 'A Hedge on Death Penalty' (28 April).

Detroit News (1976b) “Gallows Noose Swung Only Twice in Michigan' (6 Dec.): 3A, 4A.

Detroit News (1978) 'Capital Punishment Gets Backing in Detroit Area' (24 Feb.): 1 A, $2 \mathrm{~A}$.

Detroit News (1979a) ‘Capital Punishment Gnaws at Humanity’s Innards’ (5 June): 21 A.

Detroit News (1979b) 'Dad Wants Tammi's Killers Dead' (21 Aug.).

Detroit Newe (1980) 'Most in Poll Favor Death Sentence' (17 April): 1B, 8B.

Detroit News (1981a) 'Murder is Murder: Punishment, Yes - Execution, No' (16 March): $11 \mathrm{~A}$. 
Detroit News (1981b) 'States Deadly Serious - Death Penalty Returns' (16 Sept.): $1 \mathrm{~A}, 8 \mathrm{~A}, 9 \mathrm{~A}$.

Detroit Newes (1982a) 'T-Shirt Backs Death Penalty' (18 March).

Detroit News (1982b) Political cartoon (12 July): 8A.

Detroit News (1982c) 'Rough Sketches' (15 Aug.): 19A.

Detroit News (1982d) 'Board Bars Vote on Death Penalty' (27 Aug.): 1A, 4A.

Detroit News (1983) 'Death Row Population Sets Record' (5 July): 6B.

Detroit News (1984) 'Reaction to Hanging Sent Death Penalty to Gallows' (9 Sept.): $16 \mathrm{~A}$.

Detroit News (1985a) 'Foe of Death Penalty Drives Home a Point' (8 June).

Detroit News (1985b) 'Two Opinions on Death Penalty' (15 July).

Dilulio, John J., Jr (1987) Governing Prisons: A Comparative Study of Correctional Management. New York: Free Press.

Edelman, Murray (1964) The Symbolic Uses of Politics. Urbana: University of Illinois Press.

Federal Bureau of Investigation (1983) Uniform Crime Reports US Department of Justice.

Flint Journal (1955) 'Death Penalty Won't Cut Crime Rate, Expert Says' (23 June).

Flint Journal (1980) 'Michigan and the Death Penalty' (6 Jan.): 5B.

Foucault, Michel (1977) Discipline and Punish: The Birth of the Prison. New York: Vintage.

Gongwer News Service (1984) 'Michigan Report', No. 85 (1 May).

Grand Rapids Press (1945) 'Death Penalty Bill Defeated' (7 March).

Gusfield, Joseph R. (1955) 'Social Structure and Moral Reform: A Study of the Woman's Christian Temperance Union', American Joumal of Sociology 61:22132.

Hagan, John, Edward T. Silva and John H. Simpson (1977) 'Conflict and Consensus in the Designation of Deviance', Social Forces 56: 320-40.

Helfman, Harold M. (1956) 'A Forgotten Aftermath to Michigan's Abolition of Capital Punishment', Michigan History Magazine 40: 203-14.

Ignatieff, Michael (1978) A Just Measure of Pain: The Penitentiary in the Industrial Revolution, 1750-1850. New York: Pantheon.

Kingdon, John W. (1984) Agendas, Alternatives, and Public Policies. Boston: Little Brown.

Knapp, Austin C. (ed.) (1963) State of Michigan, Constitutional Convention, 1961, Vol. 1. Lansing: State of Michigan.

Kohler, Thomas (1980) Unpublished manuscript, Cooley Law School, Lansing, Michigan.

Lansing State Journal (1931) 'Senate Committee Revamps Foster Death Penalty Bill' (11 Feb.): 1 .

Lansing State Joumal (1946) 'Capital Punishment Banned in Michigan 100 Years Ago' (11 July).

Lansing State Journal (1952) 'House OK's Death Bill for Felons' (28 May): 1, 2.

Lansing State Journal (1953) 'Death Bill Defeated in House' (12 March): 1, 16.

Lansing State Joumal (1957) 'Precedent Set by Michigan Against Death Penalty Gains Prestige' (10 April): 34, 38.

Lansing State Joumal (1967) 'Michigan's Latest Attempt: Capital Punishment Again Asked' (1 May): 4A.

Lansing State Journal (1970) 'Angry Senator Stalks Out in Death Penalty Hassle' (6 Feb.).

Lansing State Journal (1972a) 'State has Led Anti-Death Penalty Forces' (3 Feb.).

Lansing State Journal (1972b) 'Great Material for a Nightmare: Viewing 189 Executions Solidifies Opposition to Capital Punishment' (13 Aug.): 1C, 4C. 
Lansing State Joumal (1973) 'Comment During Rap Session: Two of Five Lifers Favor Death Penalty' (10 April): 6B.

Lansing State Joumal (1974a) 'Death Penalty Pushed' (14 Jan.): 1B, 4B.

Lansing State Journal (1974b) 'Hanging Never Popular in State' (14 Jan.): 4B.

Lansing State Journal (1975) 'Death Penalty Gaining Favor' (29 March).

Lansing State Joumal (1977) 'Detroit Bar Owner's Hanging Becomes Death Penalty Symbol' (10 March): 10B.

Lansing State Joumal (1979) 'New Death Penalty Petition Drive is Getting Organized' (5 Nov.).

Lansing State Journal (1980) 'Ex-Death Row Inmate Fights Death Sentence' (15 June): 1 A.

Lansing State Journal (1982) 'Death Amendment Killed: Patterson' (30 Sept.): 6B.

Lansing State Journal (1985a) 'State Republican Delegates Vote to Back Death Penalty, 1,274-310' (17 Feb.): 1A, 4A.

Lansing State Journal (1985b) 'State Bar Says No to Death Penalty' (12 May).

Lincoln, James H. (1987) 'The Everlasting Controversy: Michigan and the Death Penalty', Wayne State Law Review 33: 1765-90.

Lee, Alfred McClung and Norman Daymond Humphrey (1943) Race Riot. New York: Dryden Press.

Martin, John Barlow (1954) Break Down the Walls. New York: Ballantine.

McGarrell, Edmund F. and Timothy J. Flanagan (eds) (1985) Sourcebook of Criminal Statistics; 1984. Albany, NY: Hindelang Criminal Justice Research Center.

Michigan Catholic Conference (1985) 'The Death Penalty: A Discussion Guide', Lansing: Michigan.

Michigan Chamber of Commerce (1980) 'Executive Report. Should Michigan Bring Back the Death Penalty?' (7 April): 6, 7.

Orland, Leonard (1975) Prisons: Houses of Darkness. New York: Free Press.

Page, Ann L. and Donald A. Clelland (1978) 'The Kanawha County Textbook Controversy: A Study of Life Style Concern', Social Forces 57: 265-81.

Platt, Tony and Paul Takagi (1977) 'Intellectuals for Law and Order: A Critique of the New Realists', Crime and Social Justice 8: 1-16.

Rusche, Georg and Otto Kirchheimer (1939) Punishment and Social Structure. New York: Columbia University Press.

Saginaw News (1980) 'Let's Keep Michigan Civilized' (17 Feb.).

Tuchman, Gaye (1978) Making Neres: A Study in the Construction of Reality. New York: Free Press.

United Auto Workers (1977) Legislative Program.

United States Department of Commerce (1947-86) Statistical Abstracts of the United States, 68th to 106 th edition.

United States Department of Commerce (1975) Historical Statistics of the United States: Colonial Times to 1970, Part 1. Washington, DC: US Government Printing Office.

United States Department of Justice (1981) Capital Punishment, 1980. Bureau of Justice Statistics, Washington, DC: US Government Printing Office.

United States Department of Justice (1992) Capital Punishment, 1991. Bureau of Justice Statistics, Washington, DC: US Government Printing Office.

Wood, Michael and Michael Hughes (1984) 'The Moral Basis of Moral Reform: Status Discontent vs. Culture and Socialization as Explanations of Anti-pornography Social Movement Adherence', American Sociological Review 49: 86-99.

Widick, J. B. (1972) Detroit: City of Race and Class Violence. Chicago: Quadrangle Books.

Zimring, Franklin E. and Gordon Hawkins (1986) Capital Punishment and the American Agenda. Cambridge: Cambridge University Press. 


\section{CAse Cited}

Furman v Georgia (1972) 92a Supreme Court Reporter 2726 (29 June).

\section{Legislation Cited}

Michigan Revised Statutes (1846) Ch. 152-3: 658, effective 1 Jan. 1847. Michigan House Bill 482 (1952) Journal of the House 14 May.

Michigan Constitution (1963) Article 4, Section 46 Death Penalty.

Michigan Laws (1973) Michigan Public Act 112. (19 Aug.).

\section{Legislative Reports and Hearings Cited}

in:

Michigan Legislature (1844) House Majority Report of the Select Committee on Abolishment of Capital Punishment.

Michigan Legislature (1865) Senate Report of the Judiciary Committee.

Michigan Legislature (1929) Journal of the House.

Michigan Legislature (1929) Journal of the Senate.

Michigan Legislature (1931) Journal of the House.

Michigan Legislature (1931) Journal of the Senate.

Michigan Legislature (1943) Journal of the House.

Michigan Legislature (1973) House Hearings of the Committee on Constitutional Revision and Women's Rights, 15 March.

Michigan Legislature (1985) Journal of the Senate.

Michigan Legislature (1985) Senate Judiciary Committee, Hearing on Capital Punishment, 23 May. 